\title{
ASSESSMENT OF AFLATOXINS IN SOME FOODS AND ITS RELATION TO HEPATIC DISEASES
}

\author{
Abdel Razek, T. A. ${ }^{(1)}$; El Sayed, Hanaa, H. ${ }^{(2)}$; Abdo, E. F. ${ }^{(3)}$ \\ and Ali, Hend, $M$.
}

1) Institute of Environmental Studies and Research, Ain Shams University

2) The National Nutrition Institute 3) Faculty of Medicine, Assiut University

\begin{abstract}
Humans are exposed to hepatocarcinogenic aflatoxins (Afs) through ingestion of contaminated foods as a result of poor storageful of susceptible grains or eating foods contaminated with aflatoxins animals and vegetables. This work aimed at evaluating the effect level of total (Afs) on human health. Study samples ninety persons divided into three groups (each /30 human). Group (1) no suffering liver disease as normal or negative control. Group (2) patients input (El Raghi hospital in Assuit) are suffering of liver inflammatory disease (HI). Group (3) patients input/or output (El Raghi hospital in Assuit) are suffering of hepatocellular carcinoma (HCC). Random samples were obtained from some foods (chicken egg; chicken, duck and rabbit liver) purchased from local market in Assuit. Total amount of aflatoxins was determined by using high-performance liquid chromatography (HPLC) instrumental.

This study used $24 \mathrm{~h}$ recall and food frequency questioners for these groups to determination the type and amount of food which were intake. In serum humans measured total aflatoxins by used the enzyme-linked immunosorbent assay (ELISA) kits and ELISA technique. In addition oxidation tests are carried out for the studied individuals by using colorimetric kites to determine liver function (Alanine transaminase (ALT), Aspartate transaminase (AST), Total protein (TP), albumin (Alb), Bilirubin (Total, Direct), alkaline phosphatase (ALP), Glutathione peroxidase (GPX) and Malondialdehyde (MDA) by used spectroscopy instrument.

Results indicated that were significant increase in liver function and biomarker antioxidants (GPX, MDA). Study concluded that these alterations in liver functions could be related to the development of liver damage in
\end{abstract}


response to significant dose of Aflatoxins and this work aimed at evaluating the effect level of total (Afs) on human health.

Key words: Aflatoxins- health of humans- liver disease.

\section{INTRODUCTION}

WHO (2014) reported that there are lots of environmental toxins in our air, water and/or food supply affecting of humans health. Food contamination is a public health problem that is monitored worldwide. Fehizardo and Camara (2013) found that care in food preparation and storage is so serious to avoid intake of various microorganisms and their toxins.

Liu \& Wu (2010) showed that aflatoxins are a group of approximately 20 related fungal metabolites. The four major aflatoxins are known as B1, B2, G1, and G2. Aflatoxins B2 and G2 are the dihydro-derivatives of the parent compounds B1 and G1.Aflatoxins refer to serious health, economic and agricultural problems in developing countries Afum et al. (2016)

The biosynthetic pathway of aflatoxins consists of 18 enzymatic steps for conversion from acetyl-CoA, and at least 25 genes encoding the enzymes and regulatory pathways have been cloned and characterized (Yabe and Nakajima, 2004).

Wild et al. (2002) indicated that aflatoxins (AFL) contaminate food during storage, production and processing. Due to their high toxicity and carcinogenic effects, they have long been suggested as possible an etiologic agent of hepatocellular carcinoma (HCC). Jaimez et al. (2000) the level of toxicity associated with aflatoxin varies with the types present, with the order of toxicity being AFTs-B1 > AFTs-G1 > AFTs-B2 > AFTs-G2. Reddy et al. 
(2010) who said that excreted aflatoxins metabolites were related to have an increased risk of HCC.

The adverse health effects of aflatoxins can be categorized as either acute or chronic. Acute aflatoxicosis occurs when moderate to high levels of the toxins are consumed and may result in hemorrhage, acute liver damage, edema of the limbs, alteration in digestion ( absorption and/or metabolism of nutrients), high fever, vomiting, swollen livers and possibly death Verma (2004).

Chronic aflatoxicosis is results from ingestion of low to moderate levels of aflatoxins and the effects are usually subclinical and difficult to recognize CDC (2004).

WHO (2014) reported that liver cancer is the sixth most common cancer worldwide, with 782,000 new cases diagnosed in 2012. It is the second most common cause of death from cancer and is more common in men than women. Hepatocellular carcinoma (HCC) accounted for 70\%-90\% of primary liver cancers, making it the third leading cause of cancer-related deaths worldwide El-Serag et al. (2007).

This study carried out on aflatoxin in some food that may be the cause liver diseases in humans and relation between Aflatoxin in foods and HCC in humans.

\section{MATERIALS, SUBJECT AND METHODS}

\section{Materials:}

- Foods: chicken egg; chicken, duck and rabbit liver, purchased from local market in Assuit. 
- Kits and chemical for analysis will obtained from El Gomhoria com., Sigma (St. Louis, MO, USA) and Merck (Darmstadt, Germany).

\section{Subjects:-}

90 studied groups (30 normal; 30 inflammation liver and $30 \mathrm{HCC}$ ) were obtained from El Raghy Hospital for liver diseases.

\section{Methods:}

- Dietary Assessment for patient by measure the quantity of food items consumed over one day period "twenty four-hour recall" The second methods included the dietary pattern by a questionnaire of food frequency method according to NNI, 2006 and then analyze quantity for some Aflatoxins in some foods by using HPLC according to Sirhan et al., (2011), Determinate liver function (enzymes, natural antioxidant and lipid peroxidation) by spectrometer according to (Young, 2001; Tietz, 1990 \& 1995; Moss, 1982; Beutler et al., 1963 and Uchiyama \& Mihara, 1978) respectively and Aflatoxins albumin adduct using ELISA Kit for patients by using sera according to Zain (2011).

- Statistical analysis: Data were statistically analyzed of variance "ANOVA" test at $(\mathrm{P} \leq 0.05)$ according to Snedecor and Cochran (1967). 


\section{RESULTS AND DISCUSSION}

\section{Characterization of Groups:}

Table (1): Demographic data between different study groups

\begin{tabular}{|c|c|c|c|c|}
\hline \hline \multirow{2}{*}{ Sample } & Groups & $\begin{array}{c}\text { G1 } \\
\text { Normal }(\mathbf{n}=30)\end{array}$ & $\begin{array}{c}\text { G2HCC } \\
(\mathbf{n = 3 0})\end{array}$ & $\begin{array}{c}\text { G3HI } \\
(\mathbf{n = 3 0})\end{array}$ \\
\hline \hline \multicolumn{2}{|c|}{$\begin{array}{c}\text { Average age "years" } \\
\text { Range of Age: }\end{array}$} & $\begin{array}{c}42.09 \pm 13.10 \\
(20.0-70.0)\end{array}$ & $\begin{array}{c}58.83 \pm 7.60 \\
(45.0-71.0)\end{array}$ & $\begin{array}{c}63.36 \pm 11.80 \\
(35.0-89.0)\end{array}$ \\
\hline \multirow{2}{*}{ Gender } & Male & $13(43.33 \%)$ & $25(83.3 \%)$ & $23(76.7 \%)$ \\
\cline { 2 - 5 } & Female & $17(56.67 \%)$ & $5(16.7 \%)$ & $7(23.3 \%)$ \\
\hline \multirow{2}{*}{$\begin{array}{c}\text { Place of } \\
\text { treatment }\end{array}$} & Inpatient & 0 & $8(26.67 \%)$ & $25(78.123 \%)$ \\
\cline { 2 - 6 } & out patient & $30(100 \%)$ & $22(73.33 \%)$ & $5(16.67 \%)$ \\
\hline \multirow{2}{*}{ Area } & Urban & $16(53.33 \%)$ & $9(30.0 \%)$ & $14(46.67 \%)$ \\
\cline { 2 - 6 } & Rural & $14(46.67 \%)$ & $21(70.0 \%)$ & $16(53.33 \%)$ \\
\hline
\end{tabular}

Demographic data of study groups with mean age 42.09 years in normal group and 58.8 in HCC group and there were mean age 63.36 years in HI group. These results in table (1) were harmony with Afum. et al. (2016) they found that the most liver diseases cases were 70\% for participants aged 25-34 years. 
Table (2): Value of Aflatoxin types in eggs and livers (chickens, rabbits and ducks)

\begin{tabular}{|c|c|c|c|c|c|}
\hline Samples & $\begin{array}{c}\text { Aflatoxins } \\
\text { maximum } \\
\text { level } \\
\text { allowed }\end{array}$ & $\begin{array}{c}\text { Liver } \\
\text { chicken } \\
(\mathbf{n}=5)\end{array}$ & $\begin{array}{c}\text { Liver } \\
\text { rabbit } \\
(\mathbf{n = 5})\end{array}$ & $\begin{array}{c}\text { Liver } \\
\text { duckling } \\
(\mathbf{n = 5})\end{array}$ & $\begin{array}{c}\text { Eggs } \\
(\mathbf{n = 5})\end{array}$ \\
\hline $\begin{array}{c}\text { AflatoxinB1 } \\
(\mathrm{ppb})\end{array}$ & - & Negative & Negative & Negative & Negative \\
\hline $\begin{array}{c}\text { Aflatoxins } \\
\text { B2 (ppb) }\end{array}$ & - & $22.2 \pm 0.2$ & $26.3 \pm 0.5$ & $22.3 \pm 1.0$ & Negative \\
\hline $\begin{array}{c}\text { Aflatoxins } \\
\text { G1 (ppb) }\end{array}$ & - & $18.8 \pm 2.0$ & $18.9 \pm 1.9$ & $18.8 \pm 1.05$ & Negative \\
\hline $\begin{array}{c}\text { Aflatoxins } \\
\text { G2 (ppb) }\end{array}$ & - & $13.5 \pm 1.4$ & $13.5 \pm 1.09$ & $13.7 \pm 2.01$ & Negative \\
\hline $\begin{array}{c}\text { Aflatoxins } \\
\text { total (ppb) }\end{array}$ & $20 \mathrm{ppb}$ & $54.6 \pm 2.5$ & $58.6 \pm 3.0$ & $54.8 \pm 3.8$ & Negative \\
\hline
\end{tabular}

Table (2) showed that the value of Aflatoxins in eggs and livers of chickens rabbits and ducks. There are no Aflatoxins B1 found in eggs \& liver,

Also about Aflatoxins B2, G1, G2 and total they are found in liver but negative in eggs which present in Assuit market. About Aflatoxins B2, G1, G2 and Aflatoxins total there are positive in liver (ducks, rabbit, and chicken), there are higher amount of total aflatoxin in all types of liver than maximum level allowed. Bryden (2012) reported that the contaminated animal feed is the major cause of exposure of these mycotoxins to animals and therefore ultimately to humans. Negative total aflatoxin in the different types of eggs these results agree with Jia. et al. (2016) found that combined aflatoxin (AF) and zeralion (ZEA) contamination showed synergistic effects for decreasing egg production, feed intake, feed conversion ratio and eggshell strength in birds. 
Table (3): Food intake of different patients from some food contain aflatoxins, mean $\pm \mathrm{SE}(\mathrm{g} / \mathrm{d})$

\begin{tabular}{|c|c|c|c|c|}
\hline Groups & $\begin{array}{c}\text { Normal } \\
\text { Group }\end{array}$ & $\begin{array}{c}\text { HCC patients } \\
\text { group }\end{array}$ & $\begin{array}{c}\text { HI patients } \\
\text { Group }\end{array}$ & $P$ value \\
\hline $\begin{array}{c}\text { Chicken liver } \\
\text { (g/d) }\end{array}$ & $13.4 \pm 18.6$ & $43.4 \pm 7.3$ & $42.67 \pm 4.8$ & $P<0.000$ \\
\hline $\begin{array}{c}\text { Rabbit liver } \\
\text { (g/d) }\end{array}$ & $15.9 \pm 1.9$ & $15.3 \pm 2.0$ & $14.5 \pm 2.8$ & $P=0.910$ \\
\hline $\begin{array}{c}\text { Duck liver } \\
\text { (g/d) }\end{array}$ & $6.6 \pm 1.4$ & $7.6 \pm 2.0$ & $12.2 \pm 1.1$ & $P<0.033$ \\
\hline
\end{tabular}

Table (3) shows food intake of different study groups from foods contains Aflatoxins. There were highly significance difference $(p<0.000)$ about chicken liver intake between different groups, also there were significance difference $(\mathrm{P}<0.05)$ between different groups about duck liver intake; but there were no significance difference between groups received rabbit liver $(\mathrm{P}>0.05)$. Food consumption pattern has dramatically changed in some countries. Socio-cultural factors such as religion, beliefs, food preferences, gender discrimination, education and women's employment all have a noticeable influence on food consumption patterns in this region. Iqbalab et al. (2014) reported that the consumption of chicken meat and eggs are increasing due to its availability on reasonable prices. However, the considerable finding levels of AFs, in chicken meat and eggs are alarming for the health as well as the economy of the country. Therefore, urgent steps should be taken to monitor and control these toxins in chicken meat products. The strict permissible limits should be implemented to avoid fungal contamination. 
J. Environ. Sci.

Institute of Environmental Studies and Research - Ain Shams University

Table (4): Glutathione Px, Aflatoxins and MDA in studied groups:

\begin{tabular}{|c|c|c|c|c|c|}
\hline Parameter & $\begin{array}{c}\text { Cut of } \\
\text { point }\end{array}$ & $\begin{array}{c}\text { Normal } \\
\text { Group }\end{array}$ & HCC group & HI Group & P value \\
\hline $\begin{array}{c}\text { Glutathione } \\
\text { GPx mg/dl }\end{array}$ & 49 & $33.94 \pm 4.8$ & $20.9 \pm 4.4$ & $15.2 \pm 1.2$ & $\mathrm{P}<0.000$ \\
\hline $\begin{array}{c}\text { MDA } \\
\mu \mathrm{mol} / \mathrm{ml}\end{array}$ & 31.9 & $31.1 \pm 0.4$ & $42.2 \pm 0.5$ & $55.3 \pm 0.7$ & $\mathrm{P}<0.013$ \\
\hline $\begin{array}{c}\text { AFB1_adduct } \\
\mu \mathrm{g} / \mathrm{L}\end{array}$ & $0.3 \_24.3$ & $18.2 \pm 3.4$ & $155 . \pm 11.9$ & $355.6 \pm 24.2$ & $\mathrm{P}<0.000$ \\
\hline
\end{tabular}

Table (4) showed that there were significant increase of MDA value between normal and patient groups ( $\mathrm{HCC}$ and $\mathrm{HI}$ ) while, noticed was a decrease in GPx value. High AFB1 adduct levels in serum of HCC and HI groups of study participant's confirm chronic dietary exposure to aflatoxin. The results were so may be due to AFs caused increased oxidative stress. In present study there was decrease in GPx enzyme in patients with HCC \& HI. The lower level of the antioxidant enzyme glutathione peroxidase in patients with cirrhosis indicated a severe oxidative stress explained by its utilization in scavenging the free radicals, this results agree with Sineque et al., (2017) that excessive generation of free radicals leads to inactivation of enzymes and decreased level of GPx enzyme activity as a result of the impaired GPx activity in patients. 
Table (5): Liver function parameters in studied groups

\begin{tabular}{|c|c|c|c|c|c|}
\hline Parameter & $\begin{array}{c}\text { Cut of } \\
\text { point }\end{array}$ & $\begin{array}{c}\text { Normal } \\
\text { Group }\end{array}$ & $\begin{array}{c}\text { HCC } \\
\text { patients } \\
\text { group }\end{array}$ & $\begin{array}{c}\text { HI } \\
\text { patients } \\
\text { Group }\end{array}$ & $\begin{array}{c}P \\
\text { value }\end{array}$ \\
\hline \hline AST (U/L) & Up to 38 & $30.3 \pm 1.7$ & $69.8 \pm 11.3$ & $106.7 \pm 13.5$ & 0.000 \\
\hline ALT (U/L) & Up to 40 & $28.5 \pm 1.6$ & $54.9 \pm 9.5$ & $73.2 \pm 8.2$ & 0.002 \\
\hline GGT (U/L) & Up to 50 & $19.5 \pm 2.1$ & $44.1 \pm 7.1$ & $92.2 \pm 12.6$ & 0.000 \\
\hline T.BIL(Umol/L) & Up to 21 & $14.9 \pm 0.5$ & $24.2 \pm 3.8$ & $57.1 \pm 14.4$ & 0.002 \\
\hline D.BIL(Umol/L) & Up to 4.25 & $3.0 \pm 0.2$ & $12.6 \pm 2.2$ & $41.4 \pm 12.2$ & 0.001 \\
\hline ALP (U/L) & $40 \_180$ & $151.4 \pm 9.2$ & $177 \pm 31.6$ & $199.5 \pm 22.9$ & 0.344 \\
\hline T.protein g/L & $64 \_83$ & $65.7 \pm 1.3$ & $63.6 \pm 1.9$ & $73.6 \pm 2$ & 0.0003 \\
\hline Albumin g/L & $48 \_54$ & 40.9 & 28.3 & 32.3 & 0.000 \\
\hline Globulin g/L & $16-29$ & $24.9 \pm 1.9$ & $35.4 \pm 2.2$ & $41.2 \pm 1.6$ & 0.000 \\
\hline
\end{tabular}

The vast majority of individuals with abnormal liver biochemistry had the parameter evidence of liver diseases. Liver disease is often reflected by biochemical abnormalities of liver function. Table (5) showed liver function in the different study groups. There were highly significance difference $(\mathrm{P}<0.000)$ between different groups in each of AST, ALB and TP and there were moderate significance difference $(\mathrm{P}<0.001)$ in each of ALT, $\mathrm{T}$. Bilirubin and D. Bilirubin. There are not significant differences between normal group and other groups in ALP value. These result agree with Ali and Nawaz, (2017) who recorded that measure the level of serum liver enzymes are commonly referred to as liver function tests, they usually reflect hepatocyte integrity or cholestasis rather than liver function is specific for liver disease, In this present study AST, ALT, GGT and ALP levels in HCC and HI groups often are higher than AST level in normal groups. 
J. Environ. Sci.

Institute of Environmental Studies and Research - Ain Shams University

\section{CONCLUSION}

In conclusion, the results of the present investigation exposure to low concentration of aflatoxin consumption of food for long time are cause HI and HCC. Consequent upon this, humans should avoid the contaminated food and using storage ways for foods healthy, protect animals from contaminated feed by helping the government.

\section{REFERENCES}

Afum, C.; Cudjoe, L.; Hills, J.; Hunt, R.; Padilla, L. A.; Elmore, S.; Afriyie, A.; Opare-Sem, O.; Phillips, T. \& Jolly, P. E. (2016): Association between Aflatoxin M1 and Liver Disease in HBV/HCV Infected Persons in Ghana, Int J Environ Res Public Health.; 13(4): 37.

Ali, S. \& Nawaz, W. (2017): Optimizations of nutritional requirements for dopamine synthesis by calcium alginate-entrapped mutant strain of Aspergillus oryzae; 31(3):281-288.

Beulter, E.; Duran, O. \& Kelly, B. M. (1963): The determination of blood glutathione, J. Laboratory and Clinical Medicine, 61, 882-888.

Bryden, W. L. (2012): Mycotoxin contamination of the feed supply chain: Implications for animal productivity and feed security.

Center for Disease Control and Prevention (CDC), (2004): Outbreak of aflatoxin poisoning-Eastern and central provinces, Kenya. MMWR. 53:790-793.

El-Serag, H. B.; Lau, M.; Eschbach, K.; Davila \& Goodwin, J. (2007): Epidemiology of hepatocellular carcinoma in Hispanics in the United States. Arch Intern Med. 167:1983-1989.

Felizardo, R. J. \& Câmara, N. O. (2013): Hepatocellular carcinoma and food contamination: Aflatoxins and ochratoxin A as great prompter. World J Gastroenterology.; 19(24): 3723-3725. 
Hemelrijck, V. M.; Jassem, W.; Walldius G.; Fentiman, I. S.; Hammer, N; Lambe, M.; Garmo, H.; Jungner, I. \& Holmberg, L. (2011).: Gamma-glutamyltransferase and risk of cancer in a cohort of 545,460 persons - the Swedish AMORIS study. Eur. J. Cancer; 47: pp. 2033-2041.

Iqbalab, S. Z; Nisar, S.; Rafique, M. \& Jinapbd, A. S. (2014): Natural incidence of aflatoxins, ochratoxin A and zearalenone in chicken meat and eggs), Food Control Volume 43, Pages 98-103.

Jaimez, J.; Fente, C. A.; Vazqueza, B .I.; Francoa, C. M.; Cepeda, A.; Mahuzierb, G. \& Prognonb, P. (2000): Application of the assay of aflatoxins by liquid chromatography with fluorescence detection in food analysis. Journal of Chromatography A, 882, (1-2,) P 110.

Jia, R.; Ma, Q.; Fan, Y.; Ji, C.; Zhang, J.; Liu, T. \& Zhae, L. (2016): The toxic effects of combined aflatoxins and zearalenone in naturally contaminated diets on laying performance, egg quality and mycotoxins residues in eggs of layers and the protective effect of Bacillus subtilis biodegradation product, Food and Chemical Toxicology, 90,: P 142-150.

Kirk, G. D.; Bah, E. \& Montesano, R. (2006): Molecular epidemiology of human liver cancer: insights into etiology, pathogenesis and prevention from the Gambia, West Africa. Carcinogenesis; 27: pp. 2070-2082.

Liu, Y. \& Wu, F. (2010): Global Burden of Aflatoxin-Induced Hepatocellular Carcinoma: A Risk Assessment Environ Health Perspect; DOI: Environ. Health Perspect, 118:818-824.

Moss, D. W. (1982): Alkaline phosphates isoenzymes. Clin. Chem. 28:20072016.

National Nutrition Institute NNI, (2006): Method of food pattern.

Reddy, L. \& Bhoola, K. (2010): Ochratoxins-food contaminants: impact on human health. Toxins (Basel); 2:771-779.

Snedecor, G. W. \& Cochran, W. G. (1967): Statistical Methods.7th Ed., the Iowa State University Press, Ames, Iowa, U.S.A. 
Sineque, A. R; Macuamule, C. L. \& Anjos, F. R. D. (2017): Aflatoxin B1 Contamination in Chicken Livers and Gizzards from Industrial and Small Abattoirs, Measured by ELISA Technique in Maputo, Mozambique. Int. J. Environ. Res. Public Health 14, 951.

Sirhan A. Y.; Tan, G. H. \& Wong, R. C. S. (2011): Method validation in the determination of aflatoxins in noodle samples using the QuEChERS method (Quick, Easy, Cheap, Effective, Rugged and Safe) and high performance liquid chromatography coupled to a fluorescence detector (HPLC-FLD). JFCO2223, 1-7.

Tietz, N. W. (1990): Clinical guide to laboratory tests. $2^{\text {nd }}$ ed. Philadelphia: WB Saunders; PP. 26-29.

Tietz, N. W. (1995): Clinical guide to laboratory tests. $3^{\text {rd }}$ ed. Philadelphia: WB Saunders PP. 268-273.

Uchiyama, M. \& Mihara, M. (1978): Determination of malonaldehyde precursor in tissues by thiobarbituric acid test. Analytical Biochemistry, 86(1), 271-278.

Verma, R. J. (2004): Aflatoxin causes DNA damage. Int. J. Hum. Genet. 4: 231-236.

World Health Organization (2014); Switzerland: Geneva: Trace Elements in Human Nutrition and Health.

Wild, C. P. \& Turner, P. C. (2002): The toxicology of aflatoxins as a basis for public health decisions. Mutagenesis; 17:471-481.

Yabe, K. \& Nakajima, H. (2004): Enzyme reactions and genes in aflatoxin biosynthesis. Applied microbiology and biotechnology, V 64, (6,) 745-755.

Young, D. S. (2001): Effects of disease on Clinical Lab. Tests, 4thed AACC.

Zain, M. E. (2011): Impact of mycotoxins on humans and animals, Journal of Saudi Chemical Society, 15(2): 129-144 


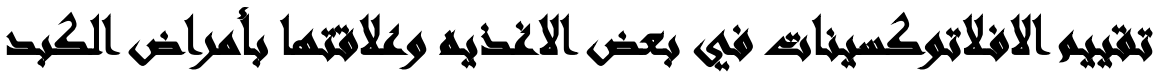

\section{[r]}

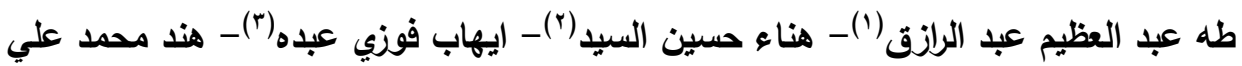

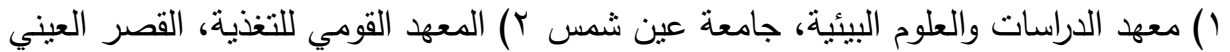

$$
\begin{aligned}
& \text { r) كلية الطب، جامعة أسيوط }
\end{aligned}
$$

\section{المستخليف (t)}

يتعرض الإنسان لإصابة الكبد بالأفلاتوكسينات من خلال تتاول الأطعمة الملوثة نتيجة للتخزين

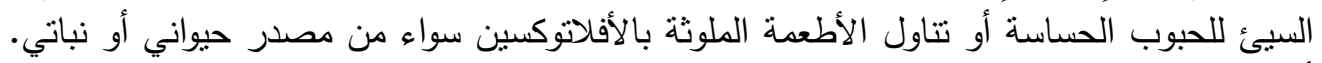

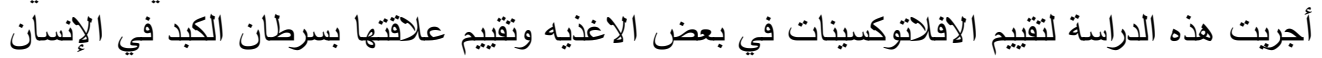

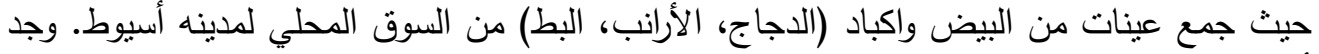

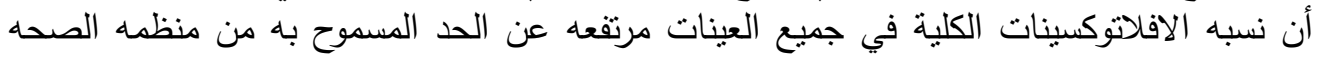

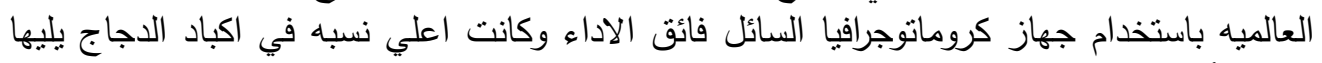
اكباد الأرانب ثم اكباد البط.

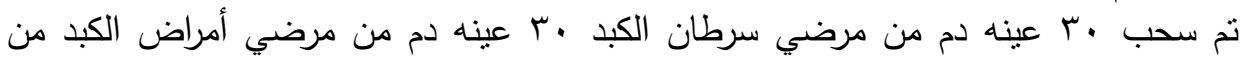

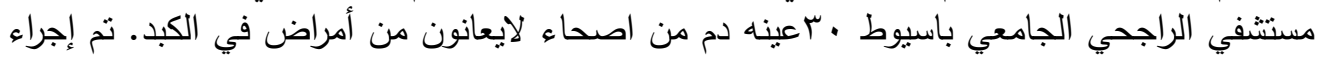



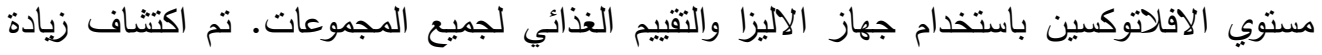
واضحة في إنزيمات الكبد لدي مرضي سرطي الذبان الكبد مع زياده مستوي الافلاتوكسين في دم المرضي.

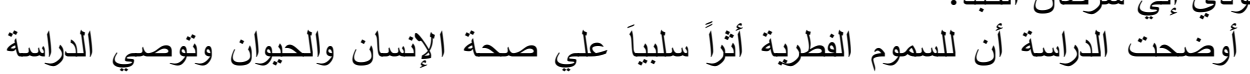
وقد تودي إلي سرطان الكبد.

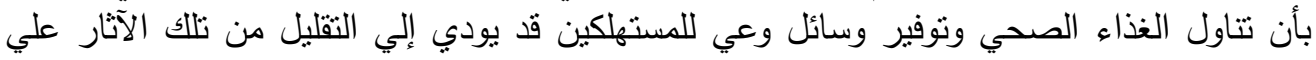
صحة الإنسان والحيوان. الكلمات الدالة: (الأفلاتوكسينات - أمراض الكبد - صحة الإنسان). 